\title{
Riparian and Riverine Wildlife Response to a Newly Created Bridge Crossing
}

\author{
Joshua A. Vance ${ }^{1}$, Norse B. Angus ${ }^{2}$, James T. Anderson ${ }^{1 *}$ \\ ${ }^{1}$ West Virginia University, Division of Forestry and Natural Resources, Morgantown, USA; ${ }^{2}$ West Virginia Department of Transpor- \\ tation, Division of Highways, Charleston, USA. \\ Email: *jim.anderson@mail.wvu.edu
}

Received September $11^{\text {th }}, 2012$; revised October $23^{\text {rd }}, 2012$; accepted November $4^{\text {th }}, 2012$

\begin{abstract}
Construction of man-made objects such as roads and bridges can influence wildlife presence and abundance. We investtigated waterbirds, songbirds, anurans, turtles, small mammals, and furbearers along the Ohio River, WV, at a new bridge crossing, a 45-year-old bridge, and 1 or 2 islands with no bridge and at 3 distances from the bridge or center point at each site $(0 \mathrm{~m}, 100 \mathrm{~m}$, and $300 \mathrm{~m})$. We sampled 19 waterbird, 60 songbird, 7 anuran, 5 turtle, 9 small mammal, and 4 furbearer species. Great blue heron (Ardea herodias) abundances were greater at the site with no bridge. Songbird composition differed among sites and between transects under and away from the bridge with higher abundances or association of rock pigeon (Columba livia) and cliff swallow (Petrochelidon pyrrhonota) under the bridges and lower abundances of Carolina wren (Thryothorus ludovicianus) and common yellowthroat (Geothlypis trichas) under the bridges. Total small mammal abundance, diversity, and richness were lower under the new bridge compared to other sites and distances. We conclude that overall the new bridge is causing minimal relative abundance impacts to wildlife. However, great blue heron abundance may be altered due to noise and activity from the presence of the bridge and minor short-term impacts to some songbirds and small mammals directly under the bridge in the form of habitat conversion, fragmentation, and loss due to removal of vegetation is apparent.
\end{abstract}

Keywords: Great Blue Heron; Road Effects; Small Mammals; Songbirds; Waterbirds

\section{Introduction}

Humans today are affecting natural ecosystems at extraordinary rates through conversion of land and resource consumption [1], alteration of habitat and species composition [2], disruption of hydrological processes [3], and modification of energy flow and nutrient cycles [4]. Since the 1940s, the human population of the United States has become increasingly urbanized [5]. Urbanization dramatically alters landscapes through habitat fragmentation and increased human presence. Urbanization and the construction of roads and bridges can alter wildlife habitat, and is cited as the second most frequent cause of species endangerment, behind agriculture, in the United States [6]. Construction of these man-made objects may have temporary or permanent effects on wildlife and vegetation. Historically, relatively few published studies have evaluated these effects. Recently, more attention has been directed toward the effects of bridges and roads upon wildlife and vegetation $[7,8]$.

Bridges can potentially affect mammals, birds, amphibians, and reptiles either positively, negatively, or have no

${ }^{*}$ Corresponding author. effect depending on species or location. Bridges have positive effects on wildlife by providing habitat for nesting, roosting, and resting as well as providing corridors for movement. Cliff swallows (Petrochelidon pyrrhonota) and barn swallows (Hirundo rustica) are species that use bridges for nesting and perching $[9,10]$. Additionally, peregrine falcons (Falco peregrinus) have been well documented as using bridges and skyscrapers for nesting sites and hunting perches [11]. Other research shows that bridges provide roosting and resting habitat for bats [12]. Edge created by roads and bridges may provide habitat for certain songbirds and increase their population [13].

There is a lack of published literature on the ecological impacts of bridges on wildlife. However, the presence of a bridge may have direct negative impacts on wildlife similar to those of highway impacts which have been studied in much greater detail. Some of these negative impacts include: increased mortality from vehicle collisions $[14,15]$, noise [16], barrier effects $[17,8]$, and attraction of undesirable or non-native species [18]. Bridges and highways also can impact the landscape causing habitat fragmentation [19], habitat loss [20], and habitat alteration [21] which in turn are negative for some wild- 
life. This can lead to species declines and disruption of continuous population distributions, limit movements, and cause potential genetic problems.

The purpose of this study was to evaluate the shortterm impacts and effects of the Blennerhassett Island Bridge as it crosses over the Ohio River and Blennerhassett Island near Parkersburg, West Virginia, USA. The Blennerhassett Island Bridge is a tied-arch style singlespan bridge [22] about $1220 \mathrm{~m}$ in length and about $24 \mathrm{~m}$ above the island and water with 3 piers on the island. Construction of the bridge began in May 2005 and it was opened to the public 13 June 2008. This study investigated waterbird, songbird, anuran, turtle, small mammal, and furbearer relative abundance and overall wildlife mortality and compared results to 2 other islands (1 with an old bridge crossing and 1 with no bridge crossing) and also at 0,100 , and $300 \mathrm{~m}$ from the bridge. Comparisons for anurans and turtles also were made to an additional island with no bridge crossing.

\section{Materials and Methods}

\subsection{Field-Site Description}

This study was conducted along the Ohio River in Wood County and Pleasants County, West Virginia and Washington County, Ohio, USA (39 $\left.16^{\prime} 12^{\prime \prime} \mathrm{N}, 81^{\circ}, 38^{\prime} 47^{\prime \prime} \mathrm{W}\right)$. There were 4 sites (Blennerhassett Island, Buckley Island, Muskingum Island, and Grape Island) and surveys were conducted on both the islands and the adjacent mainland. Blennerhassett and Buckley both had bridge crossings, but Muskingum and Grape did not and one or the other was used as a control site for some surveys. These islands occur between $\mathrm{km}$ markers 244.0 and 305.6 (mi markers 151.6 and 189.9). Blennerhassett, Buckley, and Muskingum are located in the Belleville Navigational Pool, and Grape Island is located in the Willow Island Navigational Pool [23].

Blennerhassett Island is owned by Dupont Corporation and is leased to the state of West Virginia as a state historical park. Buckley, Muskingum, and Grape islands are owned by the U.S. Fish and Wildlife Service and are part of the Ohio River Islands National Wildlife Refuge. Precipitation occurs throughout the year, totaling about 106 $\mathrm{cm} /$ year [24]. The elevation of the study area ranges from $184-198 \mathrm{~m}$. The primary cover types for these islands are: bottomland hardwood forest, late old-field, and early old-field [23]. Additionally, both Blennerhassett and Grape islands contain a palustrine unconsolidated bottom wetland. All islands in this study area have been historically used for agriculture and the river channels around them may have been historically dredged [23]. The adjacent mainland has been characterized by disturbance from urbanization, agriculture, commercial development, and industrial expansion. Both back and main channels of Ohio River islands provide critical riparian wildlife habitat for many species of birds, aquatic mammals, frogs, and turtles [25].

\subsection{Study Design}

Waterbirds, songbirds, anurans, turtles, small mammals, and furbearers were sampled at Blennerhassett Island (new Rt. 50 bridge), Buckley Island (existing I-77 bridge), and Muskingum Island (no bridge). Anurans and turtles were sampled at Grape Island (no bridge) due to the presence of a wetland, but due to the island's small size, other taxa were not sampled. Songbirds, anurans, small mammals, and furbearers were sampled along $100 \mathrm{~m}$ transects placed under the bridge or island center, if there was no bridge (0), and at 100 and $300 \mathrm{~m}$ from the central transect with transects starting at the shorelines on both sides of the bridge on the mainland and on the island. Ideally our study would have had transects on both shores of the island as well as on the West Virginia and Ohio mainland ( $n=20$ at each site). Because of site constraints (e.g., size of island, industry, agriculture, rock quarry, commercial and residential development) only 37 of the 80 proposed transects among the 4 sites could be sampled for all taxa except turtles: Blennerhassett Island $(n=15)$, Buckley Island $(n=12)$, Muskingum Island $(n$ $=7)$, and Grape Island $(n=3)$. Because turtle trapping occurred at the terminal ends of the transects in the main river, all 20 transects could be sampled at each site. Additionally, turtle trapping was conducted in the slough on Blennerhassett Island, and was planned in the slough on Grape; however, water levels were not deep enough to trap. This provided 85 trap locations for turtles $(n=25$ at Blennerhassett, $n=20$ at Buckley, $n=20$ at Muskingum, and $n=20$ at Grape). Comparisons were made among sites (waterbirds, songbirds, anurans, small mammals, furbearers, mortality) and/or distance from bridge (songbirds, anurans, turtles, small mammals, and furbearers).

\subsection{Waterbirds}

Waterbird surveys were conducted by a single observer during 90 minute complete scan counts while sitting on the mainland facing the island and monitoring the river, air, riparian zones, and part of the island in a 39.25 ha area (semicircle with a $500 \mathrm{~m}$ radius from the observation point) using $8 \times 42$ power binoculars and a 15 to 60 power, $60 \mathrm{~mm}$ zoom, Bausch and Lomb ${ }^{\circledR}$ spotting scope. Surveys were conducted from 1 hour before sunset to 30 minutes after sunset (dusk) and then 30 minutes before sunrise to 1 hour after sunrise (dawn) at the same location the following morning [26]. The dusk survey and the dawn survey the following morning were combined into one single survey and the maximum count for each species between the two times was used. During these 
counts, all waterbirds observed were enumerated and recorded [27,28] and flyovers were categorized by whether the individuals flew over or under the bridge. Waterbirds were considered waterfowl, seabirds, shorebirds, wading birds, and belted kingbirds (Megaceryle alcyon) [29]. The distance from the observer to the bird was measured with a Nikon Laser ${ }^{\mathrm{TM}} 12007 \times 25$ power range finder to make accurate estimations on whether the birds were within the 39.25 ha area.

Waterbird counts were conducted twice a month during October, November, and December 2007 and 2008, as well as March, April, and May 2008 and 2009. Dusk and dawn surveys were conducted from the West Virginia mainland once a month and then from the Ohio mainland later in the month because each side of the island had a different 39.25 ha area to be surveyed and to ensure the entire river channel around the island was surveyed monthly. Observation points were placed at suitable locations with clear viewing of the river, air, riparian zones, and the bridge (where applicable), but were not correlated to transects. Counts were not recorded if the wind speeds exceeded $16 \mathrm{~km} / \mathrm{hr}$ or during high flow conditions and were made up at the next available time [30].

\subsection{Songbirds}

Breeding bird surveys for songbirds were conducted along each of the $100 \mathrm{~m}$ transects using the dependent double observer method [31]. This method involved 2 observers recording data together on a single data sheet with 1 observer designed as the primary observer and the other designated as the secondary observer. The primary observer verbally dictated the number of each species detected while the secondary observer recorded the information. The secondary observer verified observations and also recorded birds that the primary observer did not detect [31]. This technique was not used to calculate detection probabilities due to low number of observations, but to verify accuracy of species identifications and counts.

Songbirds were sampled by walking along each transect for a total of 15 minutes each, pausing to identify and record all birds observed or heard. Only songbirds detected within a 1 ha area $(\leq 50 \mathrm{~m}$ perpendicular to the transect) were included in transect data. Those species detected outside or as flyovers were recorded but not included in any estimates. There were 3 scheduled stops of 3 minutes each at the beginning, middle, and end of each transect. The species, sex, age, and estimated distance of all birds detected by sight and sound was recorded. Estimated distances were recorded perpendicular to the transect using a Nikon Laser ${ }^{\mathrm{TM}} 12007 \times 25$ power range finder. Surveys were conducted from 600 to 1000 , but were not conducted during rainy or windy weather.
Surveys were conducted during the breeding season in May and June 2008 and 2009.

\subsection{Anurans}

Anuran communities were evaluated using nocturnal call count surveys to evaluate species and relative abundance [32]. To account for temporal breeding differences among species, surveys were conducted over 3 periods (period 1:25 February-25 March 2008 and 2009, period 2:8 April6 May 2008 and 2009, and period 3:27 May-24 June 2008 and 2009) based on recommended temperature ranges for different survey periods (period $1: \geq 5.6^{\circ} \mathrm{C}$; period 2 : $\geq 10^{\circ} \mathrm{C}$; period 3 : $\geq 12.8^{\circ} \mathrm{C}$ ) [32]. Surveys were conducted between 30 minutes after sunset to midnight because calling activity is generally greater before midnight. Surveys were conducted along the $100 \mathrm{~m}$ transects by slowly walking each transect for 15 minutes with 3 scheduled stops of 3 minutes at the beginning, middle, and end of each transect. There was a 1 - 2 minute settling period for disturbance caused while walking to the transects before surveys began.

Anurans were identified to species and abundances were evaluated by assigning a Wisconsin Index (WI) value of intensity of each species' call [33]. The WI ranked species from 0 - 3 based on overlap of calls and determination of individuals. A value of 0 indicated that no individuals of that species were heard. A value of 1 indicated that calling individuals could be counted and there were no overlapping calls. A value of 2 indicated that calls could be distinguished but there was some overlap. A value of 3 indicated a full chorus with continuous calling and overlapping calls. For values of 1 or 2 , the number of calling individuals was estimated. If a WI value of 3 was assigned to a species, a mandatory abundance estimate of 50 was used because numbers were impossible to estimate [32]. The date, time, temperature, and weather conditions were recorded before each survey. Surveys were not conducted if winds exceeded $20 \mathrm{~km} / \mathrm{hr}$ or if temperatures were below the minimum for each period. Estimated distance from the transect to the calling anurans also was recorded and mapped to lessen the chances of double-counting.

\subsection{Turtles}

Turtle trapping was conducted using turtle hoop nets [25]. Hoop nets were nylon, $1.5 \mathrm{~m}$ long $\times 0.9 \mathrm{~m}$ diameter with $5 \mathrm{~cm}$ mesh (Memphis Net and Twine Company, Inc., Memphis, TN). Traps were baited each day with chopped fish (either canned or frozen) contained in nylon mesh bags and suspended from the center hoop of each trap. If possible, traps were placed in areas suitable for turtles such as sand or gravel bars, areas of emergent vegetation, or areas of woody debris. Traps were set for 3 consecu- 
tive nights and checked each morning. A trap night was considered as 1 trap found completely intact the day after being set. Traps with bait missing also were considered as 1 trap night, since the opportunity to capture a turtle by scent remained. A trap found with a hole torn in it $\leq$ $18 \mathrm{~cm}$ in diameter was considered 0.5 trap night, since the potential to capture larger turtles $(>18 \mathrm{~cm}$ carapace width) remained. Missing traps, those found to be collapsed, and those with holes $>18 \mathrm{~cm}$ were all considered 0 trap nights. All turtles captured were identified, measured, weighed, and released at the capture site. Hardshell turtles were marked by shell notching [34], and softshell turtles were marked along the edge of the carapace using a leather punch [35]. Turtle trapping was conducted during July and August 2008 and June and July 2009.

\subsection{Small Mammals}

Small mammal trapping was conducted by using Sherman live traps (small folding galvanized, $5 \times 6.4 \times 16.5$ $\mathrm{cm}$; H. B. Sherman Traps, Tallahassee, FL) to capture small mammals such as mice, voles, moles, chipmunks, and shrews. Sherman traps were placed along the $100 \mathrm{~m}$ transects at 10 stations located $10 \mathrm{~m}$ apart [36]. Three Sherman live traps were set at each station. Each trap was baited with a peanut butter rolled oats mixture wrapped with wax paper [37]. Traps were set and opened for 3 consecutive nights and were checked each morning. We deducted 0.5 trap nights for each trap tripped without a capture [37]. Corresponding transects of each site were trapped simultaneously to account for temporal variation. Each mouse, vole, chipmunk, rat, or squirrel captured was ear-tagged with a \#1005-1 monel ear tag (National Band and Tag Company, Newport, Kentucky, 41072-0430) and shrews were toe-clipped for identification [38]. Other information such as trap location, species, new or recapture, age, gender, mass, and reproductive condition also were recorded. Small mammal trapping was conducted during May, June, and July 2008 and 2009.

\subsection{Furbearers}

Scent stations were constructed and monitored to measure medium-sized mammals, carnivores, and large rodent occurrence [39]. Scent stations were established along the river banks at the terminal end of each transect. Scent stations were $1 \mathrm{~m} \times 1 \mathrm{~m}$ and made from scraped, sifted, and smoothed alluvial soil at a depth of $3-5 \mathrm{~cm}$ to make tracks more visible. Scent stations were baited with a fatty acid scent tablet placed in the center of the station. Stations were operated for 3 consecutive nights and checked every morning. Identification of all animals investigating the scent station was made by the tracks left in the scent station. Scent stations were monitored in conjunction with small mammal traps during May, June, and July 2008 and 2009.

\subsection{Statistical Analysis}

Waterbird abundance (number/39.25 ha plot) of combined waterbirds and those species representing $2 \%$ or more of detections, species richness, and Shannon Diversity Index (diversity) (dependent variables) were rank transformed [40] and compared among sites (independent variable) using a repeated measures single-factor analysis of variance (ANOVA) with an alpha level of 0.05 . A Tukey's honest significance difference multiple comparison post hoc test was used for pairwise comparisons of significant variables. Flyovers were excluded from analyses. For the islands with bridges, data on whether the birds flew over or under the bridge also were summarized to investigate response to bridge.

Songbird abundance (individuals/ha) for all species combined and for any species representing $2 \%$ or more of observations, species richness, and diversity (dependent variables) were rank transformed [40] and compared by site, distance, and the interaction term (independent variables) using a repeated measures 2-way ANOVA $(\alpha=$ 0.05 ). Because the levels of distance had no physical meaning for Muskingum, a partial analysis was conducted to examine distance only for Blennerhassett and Buckley islands. In the case where there was no significant interaction, a contrast for the effect of distance pooled across both islands was estimated and, if necessary, follow up pairwise comparisons between levels of distance were estimated. If there was a significant interaction, then the effect of distance was examined for the 2 islands on an individual basis (i.e., a simple effects analysis). A model allowing for heterogeneous variance was fitted for all variables due to nonconstant variance. Residual diagnostics were then used to verify the assumptions of the model. The test of interaction was done using untransformed data to obtain a more approximate analysis [41]. When subsequently testing main effects or contrasts, rank transformed data were used.

We initially evaluated the uniqueness of species composition by site and distance from bridge (independent variables) with PERMANOVA [42] using the Vegan package in Program R. A subsequent one at a time analysis was done using multi-response permutation procedures (MRPP) in PC-ORD version 5.10 software [43]. MRPP is a non-parametric multivariate procedure for testing the hypothesis of no differences in species composition of 2 or more a priori groups of plots [44]. For these analyses, all species that occurred less than 3 times were deleted. Individuals/ha (dependent variable) were calculated for abundance data and were relativized using a general column relativization. A Sorensen (Bray-Curtis) distance measure was used with a rank transformed dis- 
tance matrix and an alpha level of 0.05. A Sorensen community similarity index, which compares pairwise similarities, was used to evaluate songbird overlap among sites and distances.

Lastly, the affinity of species occurrence by site and by distance from bridge were calculated using indicator species analysis [45]. Indicator species analysis combines information on the species abundance at a particular treatment and the faithfulness of occurrence of a species at a particular treatment. First, an indicator value for each species was calculated with a value between 0 and 100 . A value of 0 showed no indication (i.e., no association) of the species and a value of 100 showed perfect indication of the species. Second, the statistical significance of the highest indicator value $\left(I V_{\max }\right)$ for each species was tested using a Monte Carlo test using 4999 permutations with an alpha level set at 0.05 .

Combined anuran abundances, combined call index codes (CIC), abundances and CIC of those species representing $2 \%$ or more of all detections, species richness, and diversity (dependent variables) were rank transformed [40] and compared among sites and distances (independent variables) using a single-factor ANOVA with an alpha level of 0.05. Due to anurans not being detected at Buckley or Muskingum, only Blennerhassett and Grape were used in analyses. Site comparisons for Blennerhassett and Grape used transects only in which anurans were detected. Because Grape did not have sufficient distances, distance comparisons were made only at Blennerhassett.

Turtle relative abundance (captures/100 trap nights) for combined turtles and any species representing $2 \%$ or more of all captures, species richness, and diversity (dependent variables) were rank transformed [40] and compared among sites, distances, and the interaction term (independent variables) using a 2-way ANOVA with an alpha level of 0.05 and proceeded in the same fashion as the songbird analysis with a partial analysis for distance using only Blennerhassett and Buckley islands. Data were combined over each 3 day trapping interval and over the 3 trapping periods for each individual trap giving each trap a potential of 9 trap nights. Each trapping location was counted as a replicate. Recaptures were excluded from abundance analyses.

Small mammal relative abundance (captures/100 trap nights) of combined small mammal captures and individual species representing at least $2 \%$ of total captures, species richness, and diversity (dependent variables) were rank transformed [40] and compared by site, distance, and the interaction term (independent variables) using a repeated measures 2-way ANOVA $(\alpha=0.05)$ in the same fashion as the songbird and turtle analyses. Abundance data were combined over each 3 night interval as 1 total trapping period. Deer mice (Peromyscus maniculatus) and white-footed mice (Peromyscus leucopus) were combined into a single species (Peromyscus spp.) to account for identification biases. All recaptures were excluded from analyses.

Scent station data for furbearers were analyzed based on presence or absence by $G$-tests of independence with William's correction factor. Data were combined for each scent station over the 3 consecutive nights each station was operated and over the 6 survey periods in 2 years. Data were then combined by distance for each site. Analyses were run for all furbearer species combined (whether any furbearer tracks were present) and for each individual species representing $2 \%$ or more of furbearer species identified. Analyses compared both site and distance from bridge by combining total presences and absences for each site or distance. Each adjusted $G$-statistic was tested and an alpha level of 0.05 was set. Pair wise comparisons (among sites or distances) of significant tests were analyzed similarly. Transects at Muskingum Island were not used in the distance comparison due to no bridge being present at that site.

\section{Results}

\subsection{Waterbirds}

A total of 19 waterbird species $(n=11$ at Blennerhassett, $n=8$ at Buckley, and $n=17$ at Muskingum) was observed during surveys (see [46] for a complete list). Additionally, 15 other waterbird species were observed within the study area but not during survey hours [46]. Combined waterbird abundance (individuals/39.25 ha plot) was not significantly higher at Blennerhassett compared to Buckley or Muskingum although Blennerhassett had 4 times as many waterbirds as Buckley (Table 1).

Only Canada goose (Branta canadensis) $(n=1007$, 73.6\%), double-crested cormorant (Phalacrocorax auritus) $(n=28,2.1 \%)$, great blue heron (Ardea herodias) ( $n$ $=36,2.6 \%)$, mallard (Anas platyrhynchos) $(n=124$, 9.1\%), and wood duck (Aix sponsa) $(n=54,3.9 \%)$ had enough observations to analyze separately. Canada goose, double-crested cormorant, and wood duck abundances did not differ significantly among sites (Table 1). Great blue heron abundances were greater at Muskingum than at Blennerhassett or Buckley, which were similar. Mallard abundances were similar between Blennerhassett and Muskingum, but were significantly lower at Buckley.

Overall species richness was significantly lower at Buckley than the other 2 sites (Table 1). Overall diversity differed among all 3 sites with Muskingum having the highest diversity and Buckley having the lowest. At Blennerhassett, 185 of 239 (77.4\%) observations of waterbirds flew over the bridge and 54 of $239(22.6 \%)$ flew under the bridge. At Buckley, 138 of 191 (72.3\%) observations 
Table 1. Summary of waterbird variables (abundances in the form of individuals/39.25 ha plot) with their means and standard errors for Blennerhassett, Buckley, and Muskingum islands, West Virginia, USA for 2007-2009 with same letters indicating no significance among sites (bolded means are significant at $\alpha=0.05$ ).

\begin{tabular}{|c|c|c|c|c|c|c|c|c|}
\hline \multirow{2}{*}{ Common Name ${ }^{a}$} & \multicolumn{2}{|c|}{ Blennerhassett } & \multicolumn{2}{|c|}{ Buckley } & \multicolumn{2}{|c|}{ Muskingum } & \multirow[b]{2}{*}{$F_{2,9}$} & \multirow[b]{2}{*}{$p$} \\
\hline & Mean & SE & Mean & $\mathrm{SE}$ & Mean & SE & & \\
\hline Canada Goose & $28.59 \mathrm{a}$ & 8.12 & $6.86 \mathrm{a}$ & 2.46 & $10.32 \mathrm{a}$ & 2.52 & 1.51 & 0.272 \\
\hline Double-Crested Cormorant & $0.09 \mathrm{a}$ & 0.09 & $0.00 \mathrm{a}$ & 0.00 & $1.18 \mathrm{a}$ & 1.00 & 1.44 & 0.286 \\
\hline Great Blue Heron & $0.32 b$ & 0.12 & $0.09 b$ & 0.06 & $1.23 a$ & 0.39 & 5.33 & 0.030 \\
\hline Wood Duck & $0.91 \mathrm{a}$ & 0.35 & $0.91 \mathrm{a}$ & 0.35 & $0.64 \mathrm{a}$ & 0.30 & 0.58 & 0.579 \\
\hline All Waterbirds & $33.77 \mathrm{a}$ & 7.99 & $8.82 \mathrm{a}$ & 2.53 & $19.59 \mathrm{a}$ & 4.20 & 3.38 & 0.080 \\
\hline Species Richness & $2.50 \mathrm{a}$ & 0.31 & $1.31 b$ & 0.20 & $3.50 \mathrm{a}$ & 0.35 & 5.54 & 0.027 \\
\hline Shannon Diversity Index & $0.49 b$ & 0.10 & $0.19 c$ & 0.06 & $0.85 a$ & 0.09 & 8.64 & 0.008 \\
\hline
\end{tabular}

${ }^{\mathrm{a}}$ Scientific names are found in Appendix 1.

of waterbirds flew over the bridge and 54 of 191 (27.7\%) flew under the bridge.

\subsection{Songbirds}

Songbird surveys detected a total of 60 species $(n=48$ at Blennerhassett, $n=53$ at Buckley, and $n=42$ at Muskingum) [46]. A total of 17 species resulted in enough observations to analyze separately by sites and distances (Table 2). Three of these species had a significant site by distance interaction with Carolina chickadee (Poecile carolinensis) having higher abundances at the $0 \mathrm{~m}$ transect at Muskingum than at the $0 \mathrm{~m}$ transects at Blennerhassett and Buckley, while house wrens (Troglodytes aedon) had higher abundances at the $0 \mathrm{~m}$ transects at Blennerhassett compared to the $0 \mathrm{~m}$ transects at Buckley and Muskingum, and rock pigeon (Columba livia) was only found at the $0 \mathrm{~m}$ transects at Blennerhassett and Buckley causing an interaction and indicating an overall bridge effect.

Seven species differed significantly by site. Red-winged blackbird (Agelaius phoeniceus) and song sparrow (Melospiza melodia) were higher at Blennerhassett, gray catbird (Dumetella carolinensis) and red-eyed vireo (Vireo olivaceus) were lower at Blennerhassett, Carolina wren (Thryothorus ludovicianus) and tufted titmouse (Baeolophus bicolor) were higher at Muskingum, and European starling (Sturnus vulgaris) and yellow warbler (Dendroica petechia) were higher at Buckley (Table 2). Three species significantly differed by distances. Common yellowthroat (Geothlypis trichas) and Carolina wren were lower at $0 \mathrm{~m}$ transects and European starling was higher at $0 \mathrm{~m}$ transects (Table 2). No other species significantly differed among sites, distances, or interaction.

All species that occurred less than 3 times were removed from the total species composition matrix reducing the 60 to 46 for the site analysis and 44 for the dis- tance analysis for MRPP [46]. Results of the PERMANOVA showed no evidence of a site by distance interaction $\left(F_{4,25}=0.98, p=0.53\right)$. Results of the MRPP suggest that all 3 islands have different songbird communities and that the $0 \mathrm{~m}$ transects have significantly different songbird communities than $100 \mathrm{~m}$ and $300 \mathrm{~m}$ transects $(p \leq 0.005)$. The Sorensen community similarity index comparing songbird composition among sites (0.402) and distances $(0.456)$ further indicated different communities $(p \leq 0.016)$.

Results from indicator species analysis suggest certain species were more likely to occur on particular sites and at particular distances from the bridge [46]. Song sparrow was indicative of Blennerhassett, house finch (Carpodacus mexicanus) was indicative of Buckley, and 12 species were indicative of Muskingum. Two species cliff swallow (Petrochelidon pyrrhonota) and rock pigeon were indicative of $0 \mathrm{~m}$ transects.

\subsection{Anurans}

A total of 7 anuran species were detected at Blennerhassett Island and 5 anuran species at Grape Island: spring peeper (Pseudacris crucifer), Fowler's toad (Anaxyrus fowleri), eastern American toad (Anaxyrus americanus americanus), American bullfrog (Lithobates catesbeianus), Cope's gray treefrog (Hyla chrysoscelis), pickerel frog (Lithobates palustris), and northern green frog (Lithobates clamitans melanota). Only observations of spring peeper $(n=674,88.5 \%)$, Cope's gray treefrog $(n=$ $39,5.1 \%)$, American bullfrog $(n=19,2.5 \%)$, and northern green frog $(n=18,2.4 \%)$ resulted in enough detections to analyze separately.

Combined anuran abundances (individuals/transect) were similar between Blennerhassett and Grape islands and at 0,100 , and $300 \mathrm{~m}$ transects $(p=0.400)$ [46]. Likewise, spring peeper, American bullfrog, Cope's gray 
Table 2. Summary of songbird variables (abundances in the form of individuals/ha) with their means and standard errors for Blennerhassett, Buckley, and Muskingum islands, West Virginia, USA and at 0, 100, and $300 \mathrm{~m}$ from the bridge for 2008-2009 with same letters indicating no significance among sites or distances (bolded means are significant at $\alpha=0.05$ ).

\begin{tabular}{|c|c|c|c|c|c|c|c|c|c|c|c|c|}
\hline \multirow{3}{*}{ Common Name ${ }^{a}$} & \multicolumn{6}{|c|}{ Island } & \multicolumn{6}{|c|}{ Distance } \\
\hline & \multicolumn{2}{|c|}{ Blennerhassett } & \multicolumn{2}{|c|}{ Buckley } & \multicolumn{2}{|c|}{ Muskingum } & \multicolumn{2}{|c|}{$0 \mathrm{~m}$} & \multicolumn{2}{|c|}{$100 \mathrm{~m}$} & \multicolumn{2}{|c|}{$300 \mathrm{~m}$} \\
\hline & Mean & SE & Mean & SE & Mean & SE & Mean & $\mathrm{SE}$ & Mean & $\mathrm{SE}$ & Mean & $\mathrm{SE}$ \\
\hline American Goldfinch & $0.38 \mathrm{a}$ & 0.08 & $0.60 \mathrm{a}$ & 0.12 & $0.42 \mathrm{a}$ & 0.16 & $0.35 \mathrm{a}$ & 0.13 & $0.52 \mathrm{a}$ & 0.11 & $0.53 \mathrm{a}$ & 0.12 \\
\hline American Robin & $0.82 \mathrm{a}$ & 0.14 & $0.94 \mathrm{a}$ & 0.16 & $0.67 \mathrm{a}$ & 0.20 & $0.83 a$ & 0.17 & $1.00 \mathrm{a}$ & 0.20 & $0.76 \mathrm{a}$ & 0.16 \\
\hline Carolina Chickadee & $0.33 b$ & 0.10 & $0.21 b$ & 0.07 & $1.13 a$ & 0.28 & $0.17 \mathrm{a}$ & 0.08 & $0.36 \mathrm{a}$ & 0.12 & $0.24 \mathrm{a}$ & 0.08 \\
\hline Carolina Wren & $0.84 a$ & 0.13 & $0.73 a$ & 0.15 & $1.33 b$ & 0.14 & $0.35 b$ & 0.16 & $1.05 a$ & 0.17 & $0.76 a$ & 0.14 \\
\hline Common Yellowthroat & $0.58 \mathrm{a}$ & 0.10 & $0.23 \mathrm{a}$ & 0.07 & $0.33 \mathrm{a}$ & 0.13 & $0.13 a$ & 0.07 & $0.36 a b$ & 0.10 & $0.66 a$ & 0.12 \\
\hline European Starling & $0.25 a$ & 0.14 & $1.15 b$ & 0.49 & $0.04 a$ & 0.04 & $1.48 a$ & 0.57 & $0.14 a$ & 0.08 & $0.76 a$ & 0.55 \\
\hline Gray Catbird & $0.78 b$ & 0.11 & $1.38 \mathrm{a}$ & 0.17 & $1.50 \mathrm{a}$ & 0.21 & $0.87 \mathrm{a}$ & 0.21 & $1.24 \mathrm{a}$ & 0.19 & $0.97 \mathrm{a}$ & 0.12 \\
\hline House Wren & $0.82 a$ & 0.15 & $0.31 b$ & 0.09 & $0.29 b$ & 0.13 & $0.74 \mathrm{a}$ & 0.26 & $0.67 \mathrm{a}$ & 0.15 & $0.39 \mathrm{a}$ & 0.10 \\
\hline Indigo Bunting & $0.55 \mathrm{a}$ & 0.10 & $0.60 \mathrm{a}$ & 0.10 & $0.96 \mathrm{a}$ & 0.15 & $0.52 \mathrm{a}$ & 0.16 & $0.74 \mathrm{a}$ & 0.12 & $0.42 \mathrm{a}$ & 0.09 \\
\hline Mourning Dove & $0.15 \mathrm{a}$ & 0.05 & $1.25 \mathrm{a}$ & 0.85 & $0.08 \mathrm{a}$ & 0.06 & $0.30 \mathrm{a}$ & 0.15 & $0.40 \mathrm{a}$ & 0.20 & $1.16 \mathrm{a}$ & 1.05 \\
\hline Northern Cardinal & $0.62 \mathrm{a}$ & 0.10 & $0.90 \mathrm{a}$ & 0.16 & $1.21 \mathrm{a}$ & 0.19 & $0.52 \mathrm{a}$ & 0.15 & $0.67 \mathrm{a}$ & 0.11 & $0.97 \mathrm{a}$ & 0.19 \\
\hline Red-Eyed Vireo & $0.16 b$ & 0.06 & $0.54 a$ & 0.09 & $0.79 a$ & 0.13 & $0.26 \mathrm{a}$ & 0.11 & $0.31 \mathrm{a}$ & 0.09 & $0.42 \mathrm{a}$ & 0.10 \\
\hline Red-Winged Blackbird & $1.35 b$ & 0.31 & $0.15 a$ & 0.05 & $0.21 a$ & 0.10 & $0.17 \mathrm{a}$ & 0.08 & $0.64 \mathrm{a}$ & 0.29 & $1.32 \mathrm{a}$ & 0.33 \\
\hline Rock Pigeon & $0.29 b$ & 0.12 & $0.90 a$ & 0.29 & $0.00 \mathrm{c}$ & 0.00 & $2.57 a$ & 0.51 & $0.00 b$ & 0.00 & $0.00 b$ & 0.00 \\
\hline Song Sparrow & 2.91a & 0.21 & $1.79 b$ & 0.20 & $1.83 b$ & 0.26 & $2.26 \mathrm{a}$ & 0.33 & $2.33 \mathrm{a}$ & 0.26 & $2.53 \mathrm{a}$ & 0.24 \\
\hline Tufted Titmouse & $0.20 \mathrm{~b}$ & 0.05 & $0.29 b$ & 0.07 & $1.13 a$ & 0.23 & $0.09 \mathrm{a}$ & 0.06 & $0.29 \mathrm{a}$ & 0.07 & $0.29 \mathrm{a}$ & 0.07 \\
\hline Yellow Warbler & $0.25 b$ & 0.07 & $0.65 a$ & 0.13 & $0.17 b$ & 0.08 & $0.48 \mathrm{a}$ & 0.14 & $0.50 \mathrm{a}$ & 0.13 & $0.34 \mathrm{a}$ & 0.10 \\
\hline All Songbirds & $14.60 \mathrm{~b}$ & 0.61 & $16.83 a$ & 1.22 & 18.13a & 1.01 & $15.57 \mathrm{a}$ & 1.44 & $15.12 \mathrm{a}$ & 0.82 & $16.26 \mathrm{a}$ & 1.29 \\
\hline Species Richness & $9.04 b$ & 0.38 & $9.77 b$ & 0.63 & $12.58 \mathrm{a}$ & 0.67 & $8.22 \mathrm{a}$ & 0.72 & $9.74 \mathrm{a}$ & 0.57 & $9.68 \mathrm{a}$ & 0.59 \\
\hline Shannon Diversity Index & $2.01 b$ & 0.04 & $1.98 b$ & 0.08 & $2.40 a$ & 0.06 & $1.86 \mathrm{a}$ & 0.07 & $2.04 \mathrm{a}$ & 0.08 & $2.02 \mathrm{a}$ & 0.07 \\
\hline
\end{tabular}

${ }^{\mathrm{a}} \mathrm{Scientific}$ names are found in Appendix 1.

treefrog, and northern green frog abundances did not show significant difference between sites or among distances $(p \geq 0.623)$. Call index codes for combined anurans also were similar between Blennerhassett and Grape and among 0,100 , and $300 \mathrm{~m}$ transects at Blennerhassett $(p \geq 0.400)$. Similarly, spring peeper, American bullfrog, Cope's gray treefrog, and northern green frog call index codes did not differ between sites or among distances $(p \geq 0.560)$. Species richness and diversity also were similar between sites and among distances $(p \geq 0.402)$.

\subsection{Turtles}

A total of 728 trap nights were attempted with 651 total trap nights occurring after deductions. We had 96 captures of 88 individuals from 5 species: eastern spiny softshell (Apalone spinifera spinifera), common snapping turtle (Chelydra serpentina), northern map turtle (Graptemys geographica), Midland painted turtle (Chry- semys picta marginata), and stinkpot (Sternotherus odoratus). Of these 88 individuals, a total of 11 common snapping turtles and 4 Midland painted turtles were captured in the slough on Blennerhassett Island.

Combined abundances (captures/100 trap nights) were not different among sites, distances from the bridge, or by the interaction term (Table 3). Eastern spiny softshell ( $n=46,52.3 \%)$, common snapping turtle $(n=31,35.2 \%)$, northern map turtle $(n=6,6.8 \%)$, and Midland painted turtle $(n=4,4.5 \%)$ occurred in large enough numbers to analyze separately. Eastern spiny softshell, common snapping turtle, and northern map turtle abundances did not differ significantly among sites, distances, or by the interaction term (Table 3). Midland painted turtle abundances significantly differed among sites due to that species only being captured at Blennerhassett (Table 3). Species richness did not differ among sites, distances, or by the interaction term (Table 3). Diversity differed significantly among sites due to Blennerhassett and Grape 
Table 3. Summary of turtle variables (abundances in the form of captures/100 trap nights) with their means and standard errors for Blennerhassett, Buckley, Muskingum, and Grape islands, West Virginia, USA and 0, 100, and $300 \mathrm{~m}$ from the bridge for 2008 and 2009 with same letters indicating no significance among sites or distances (bolded means are significant at $\alpha=0.05$ ).

\begin{tabular}{|c|c|c|c|c|c|c|c|c|c|c|c|c|c|c|c|c|c|c|c|c|}
\hline \multirow{3}{*}{$\begin{array}{l}\text { Common } \\
\text { Name }^{\mathrm{a}}\end{array}$} & \multicolumn{8}{|c|}{ Island } & \multirow{3}{*}{$F_{3,72}$} & \multirow{3}{*}{$p$} & \multicolumn{6}{|c|}{ Distance } & \multirow{3}{*}{$F_{2,72}$} & \multirow{3}{*}{$p$} & & \\
\hline & Blenner & hassett & Buck & dey & Muskil & igum & Grap & & & & $0 \mathrm{n}$ & & 100 & & 300 & & & & \multicolumn{2}{|c|}{ Interaction } \\
\hline & Mean & SE & Mean & $\mathrm{SE}$ & Mean & SE & Mean & SE & & & Mean & SE & Mean & $\mathrm{SE}$ & Mean & SE & & & $F_{6,72}$ & $p$ \\
\hline $\begin{array}{l}\text { Eastern } \\
\text { Spiny } \\
\text { Softshell }\end{array}$ & $9.00 \mathrm{a}$ & 2.60 & $7.81 \mathrm{a}$ & 3.53 & $6.25 \mathrm{a}$ & 3.90 & $4.67 \mathrm{a}$ & 1.32 & 0.73 & 0.537 & $6.90 \mathrm{a}$ & 3.87 & $12.59 \mathrm{a}$ & 3.85 & $7.53 \mathrm{a}$ & 2.96 & 1.47 & 0.236 & 0.70 & 0.653 \\
\hline $\begin{array}{l}\text { Northern } \\
\text { Map Turtle }\end{array}$ & $2.22 \mathrm{a}$ & 1.57 & $0.70 \mathrm{a}$ & 0.70 & $0.00 \mathrm{a}$ & 0.00 & $0.00 \mathrm{a}$ & 0.00 & 0.59 & 0.624 & $0.00 \mathrm{a}$ & 0.00 & $1.85 \mathrm{a}$ & 1.85 & $1.98 \mathrm{a}$ & 1.40 & 0.98 & 0.382 & 0.27 & 0.948 \\
\hline $\begin{array}{c}\text { Midland } \\
\text { Painted } \\
\text { Turtle }\end{array}$ & 1.83a & 1.07 & $0.00 b$ & 0.00 & $0.00 b$ & 0.00 & $0.00 b$ & 0.00 & 2.75 & 0.049 & $1.39 \mathrm{a}$ & 1.39 & $0.00 \mathrm{a}$ & 0.00 & $1.93 \mathrm{a}$ & 1.38 & 1.57 & 0.215 & 0.83 & 0.554 \\
\hline All Turtles & $19.00 \mathrm{a}$ & 3.77 & $9.92 \mathrm{a}$ & 3.46 & $9.55 \mathrm{a}$ & 3.98 & $11.69 \mathrm{a}$ & 2.74 & 1.88 & 0.140 & $12.46 \mathrm{a}$ & 6.04 & $20.24 a$ & 4.80 & $13.52 \mathrm{a}$ & 3.54 & 1.65 & 0.199 & 0.75 & 0.608 \\
\hline $\begin{array}{l}\text { Species } \\
\text { Richness }\end{array}$ & $0.80 \mathrm{a}$ & 0.14 & $0.47 \mathrm{a}$ & 0.12 & $0.40 \mathrm{a}$ & 0.11 & $0.80 \mathrm{a}$ & 0.16 & 2.56 & 0.062 & $0.50 \mathrm{a}$ & 0.27 & $0.78 \mathrm{a}$ & 0.13 & $0.61 \mathrm{a}$ & 0.16 & 1.43 & 0.247 & 0.94 & 0.474 \\
\hline $\begin{array}{c}\text { Shannon } \\
\text { Diversity } \\
\text { Index }\end{array}$ & $0.10 a$ & 0.04 & $0.00 b$ & 0.00 & $0.00 b$ & 0.00 & $0.10 a$ & 0.05 & 3.13 & 0.031 & $0.07 \mathrm{a}$ & 0.07 & $0.03 a$ & 0.03 & $0.07 \mathrm{a}$ & 0.05 & 0.20 & 0.820 & 1.50 & 0.190 \\
\hline
\end{tabular}

${ }^{\mathrm{a}}$ Scientific names are found in Appendix 1.

differing from Buckley and Muskingum, but did not differ by distance, or by the interaction term (Table 3).

\subsection{Small Mammals}

A total of 16,448 trap nights were attempted with 14,625 total trap nights calculated after deductions yielding a total of 1124 captures of 733 individuals. A total of 9 small mammal species were encountered during trapping surveys [46]. Peromyscus spp. $(n=495,67.5 \%)$, meadow vole (Microtus pennsylvanicus) $(n=183,25.0 \%)$, and eastern chipmunk (Tamias striatus) $(n=24,3.3 \%)$ occurred in enough observations to analyze separately. Three variables, Peromyscus spp., species richness, and diversity, had a significant interaction effect (Table 4). These 3 variables had a significant interaction effect due to the $0 \mathrm{~m}$ transects at Blennerhassett having lower abundances, richness, and diversity under the bridge compared to 100 and $300 \mathrm{~m}$ transects. Also, the 100 and $300 \mathrm{~m}$ transects at Blennerhassett differed from the 100 and $300 \mathrm{~m}$ transects at Buckley and Muskingum due to higher abundances, richness, and diversity at the 100 and $300 \mathrm{~m}$ transects at Blennerhassett.

Combined small mammal abundances differed significantly by distances due to lower abundances at the $0 \mathrm{~m}$ transects, but did not differ among sites or by the interaction term (Table 4). Meadow vole abundances differed by sites due to this species not being sampled at Muskingum, but did not differ among distances or by the in- teraction term. Eastern chipmunk abundances did not differ among sites, distances, or by the interaction term.

\subsection{Furbearers}

A total of 4 furbearer species were encountered in scent station surveys: raccoon (Procyon lotor) represented 82.8\% of all occurrences, red fox (Vulpes vulpes) 8.2\%, Virginia opossum (Didelphis virginiana) 7.5\%, and American beaver (Castor canadensis) 1.5\%. Occurrences of all furbearer species combined and Virginia opossum did not differ by site or by distance (Table 5). Raccoon occurrences differed by site and by distance with transects at 0 $\mathrm{m}$ at Blennerhassett having lower occurrences. Red fox occurrences differed by site with Blennerhassett having the highest occurrences, but not by distance (Table 5). American beaver occurrences were not tested due to too few observations.

\section{Discussion}

\subsection{Waterbirds}

Of the 5 species analyzed, only great blue heron and mallard differed among sites. Great blue heron densities were 3.84 times higher at Muskingum than Blennerhassett and 13.67 times higher at Muskingum than Buckley. This could be attributed to great blue herons being negatively impacted by the highway bridge crossings at the other 2 islands. Great blue herons prefer remoteness and 


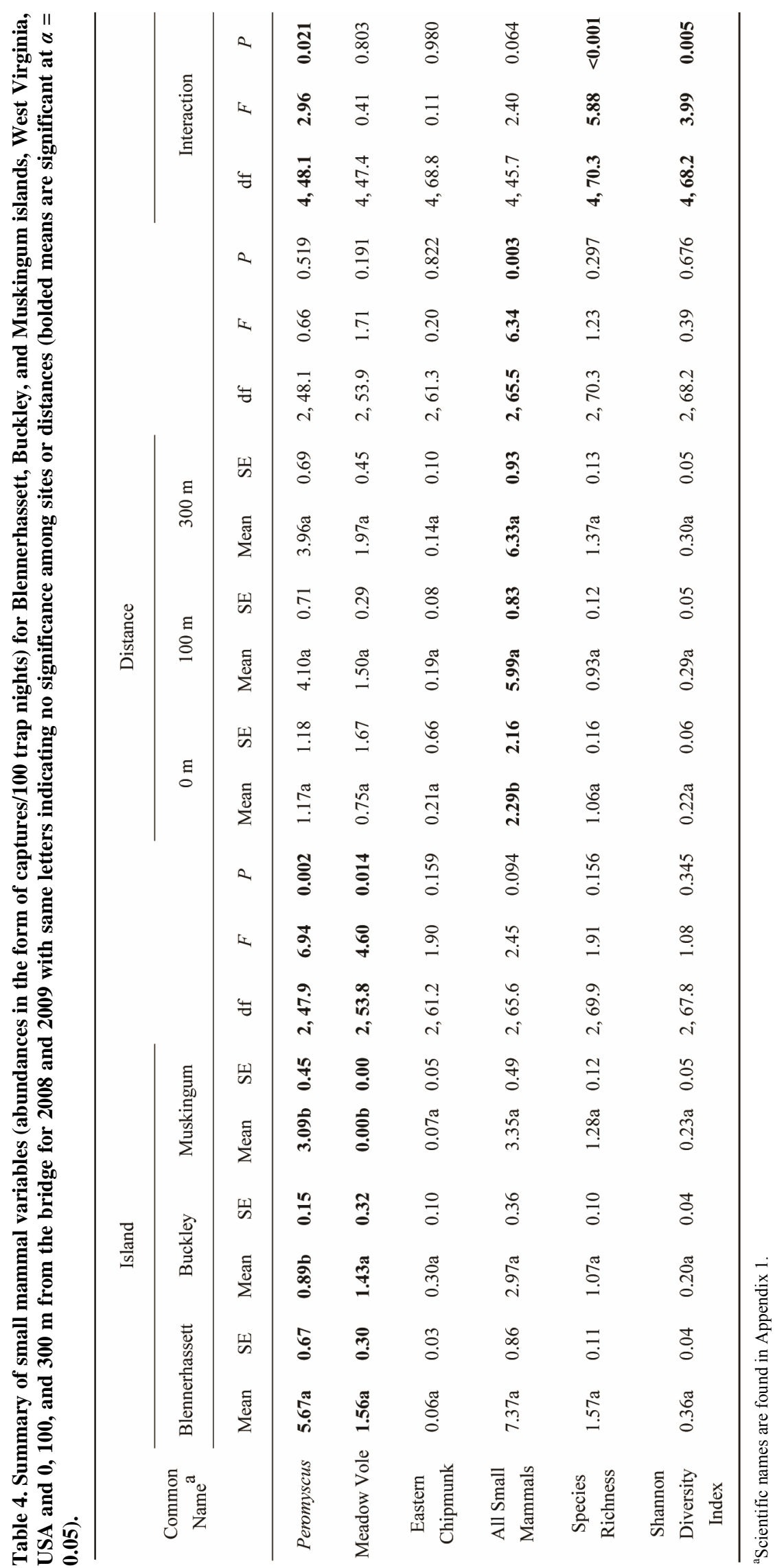


Table 5. Summary of scent station data for furbearers with their presence (P) and absence (A) percentages (\%) for Blennerhassett, Buckley, and Muskingum islands, West Virginia, USA and 0, 100, and $300 \mathrm{~m}$ from the bridge for 2008 and 2009 with the same letters indicating no significance among sites or distances (bolded species are significant at $\alpha=0.05$ ).

\begin{tabular}{|c|c|c|c|c|c|c|c|c|c|c|c|c|c|c|c|c|}
\hline \multirow{3}{*}{ Common Name ${ }^{\mathrm{a}}$} & \multicolumn{6}{|c|}{ Island } & \multirow{3}{*}{$G_{2}$} & \multirow{3}{*}{$p$} & \multicolumn{6}{|c|}{ Distance } & \multirow{3}{*}{$G_{2}$} & \multirow{3}{*}{$p$} \\
\hline & \multicolumn{2}{|c|}{ Blennerhassett } & \multicolumn{2}{|c|}{ Buckley } & \multicolumn{2}{|c|}{ Muskingum } & & & \multicolumn{2}{|c|}{$0 \mathrm{~m}$} & \multicolumn{2}{|c|}{$100 \mathrm{~m}$} & \multicolumn{2}{|c|}{$300 \mathrm{~m}$} & & \\
\hline & $\mathrm{P}$ & A & $\mathrm{P}$ & A & $\mathrm{P}$ & A & & & $\mathrm{P}$ & A & $\mathrm{P}$ & A & $\mathrm{P}$ & A & & \\
\hline Raccoon & $50.0 \mathrm{~b}$ & 50.0 & $70.8 \mathrm{a}$ & 29.2 & $69.4 \mathrm{a}$ & 30.6 & 7.39 & 0.025 & $40.6 \mathrm{ab}$ & 59.4 & $63.8 \mathrm{ab}$ & 36.2 & $69.2 \mathrm{a}$ & 30.8 & 7.00 & 0.030 \\
\hline Red Fox & $15.7 \mathrm{a}$ & 84.3 & $2.8 \mathrm{~b}$ & 97.2 & $0.0 \mathrm{~b}$ & 100.0 & 13.14 & 0.001 & $15.6 \mathrm{a}$ & 84.4 & $8.6 \mathrm{a}$ & 91.4 & $5.8 \mathrm{a}$ & 94.2 & 2.08 & 0.354 \\
\hline Virginia Opossum & $4.3 \mathrm{a}$ & 95.7 & $8.3 \mathrm{a}$ & 91.7 & $2.8 \mathrm{a}$ & 97.2 & 1.67 & 0.433 & $6.3 \mathrm{a}$ & 93.7 & $5.2 \mathrm{a}$ & 94.8 & $7.7 \mathrm{a}$ & 92.3 & 0.27 & 0.873 \\
\hline American Beaver & 0.0 & 100.0 & 2.8 & 97.2 & 0.0 & 100.0 & - & - & 6.3 & 93.7 & 0.0 & 100.0 & 0.0 & 100.0 & - & - \\
\hline All Furbearers & $60.0 \mathrm{a}$ & 40.0 & $75.0 \mathrm{a}$ & 25.0 & $49.9 \mathrm{a}$ & 50.1 & 3.66 & 0.161 & $59.4 \mathrm{a}$ & 40.6 & $67.2 \mathrm{a}$ & 32.8 & $73.1 \mathrm{a}$ & 26.9 & 1.66 & 0.436 \\
\hline
\end{tabular}

${ }^{\mathrm{a}}$ Scientific names are found in Appendix 1.

lack of human disturbance $[47,48]$. Noise can disrupt heron breeding and nesting patterns [49]. Additionally, great blue heron nesting patterns and nest success can be altered by other human disturbances including: increased human presence, land development, and destruction of habitat [50]. Mallard abundance was lower at Buckley Island possibly indicating that over time bridges impact mallards, but because mallard abundances were similar at Blennerhassett and Muskingum, we believe the Blennerhassett Island Bridge has no current impacts to mallards. There was no evidence that the Blennerhassett Island Bridge caused negative impacts to abundances of any other waterbird species.

We found waterbird species richness and diversity were lower at Buckley compared to the other 2 islands. This may be the result of the bridge at Buckley, but this is difficult to determine due to low abundances of 6 species found only at Muskingum. Lower species richness and diversity at Buckley are more easily explained by natural variation in observations rather than from the presence of a bridge.

Waterbirds do collide with bridges, which create barriers to movement and causes mortality and population declines. Our data, however, shows no indication that the bridge was a barrier or cause of mortality to waterbirds during diurnal time periods. Waterbirds more often flew over the bridge as opposed to under the bridge; however, waterbirds did not hesitate to fly under the bridge when flying low over the water. We had direct observations of many species including: belted kingfisher (Megaceryle alcyon), Canada goose, double-crested cormorant, great blue heron, mallard, spotted sandpiper (Actitis macularia), and wood duck flying under the bridge. The bridge does not seem to be a major barrier for waterbirds during flight, likely due to its relatively low height $(24 \mathrm{~m}$ above the surface). There were no observations or documentations of waterbirds colliding with the bridge during diurnal flight.

\subsection{Songbirds}

Our study indicates that the Blennerhassett Island Bridge has some, albeit minor impacts to songbirds that resulted in a decrease in overall songbird abundance and changes in species composition most likely due to the area directly under the bridge being highly disturbed and lacking woody vegetation. This effect was mostly due to the removal of all trees, snags, and coarse woody debris and may be responsible for decreases in forest interior songbirds. Rock pigeon, cliff swallow, and European starling had high affinity for transects under bridges as these are all generalist species that use bridges and other manmade structures for nesting, roosting, and perching [12]. House wrens had high abundances under the Blennerhassett Island Bridge due to the placement of songbird nest boxes under the bridge after construction.

Songbird species composition is closely related to habitat structure [51,52]. Our study echoes this as songbirds observed were closely related to known habitat preferences with habitat generalist species using the areas directly under the bridges. Muskingum Island had higher species richness and diversity, different composition, and higher abundances of forest interior songbirds than the other 2 sites. This is largely due to all transects at Muskingum Island being located in bottomland hardwood forest [46] which harbor high species richness of passerines [53] while transects at Blennerhassett and Buckley islands varied across cover types with transects in old-field habitat having lower species richness.

Changes in songbird communities found in our study follows previously documented findings on the changes in species composition following a disturbance. Songbird communities vary among successional stages and forest types, and a diversity of landscapes maintains songbird diversity. Community changes of songbirds similar to those under the bridge have been documented for many types of natural and anthropogenic disturbances includeing: fire, blow downs, timber harvests, mowing, agricul- 
ture, residential development, and urbanization [51,5457].

\subsection{Anurans}

Anurans are commonly depicted as ecologically sensitive to anthropogenic disturbance $[58,59]$. However, we found anuran abundances, richness, and diversity were not different between a site with a large bridge crossing and a site without a bridge. Also, anuran abundances, richness, and diversity were no different at the different distances at Blennerhassett Island. Species were found calling throughout the wetland complex on the island and also in the wetland vegetation under the bridge on the West Virginia mainland. This indicates that the bridge had no negative effect on anuran relative abundance. Calling indices did not differ between sites or among distances further indicating the Blennerhassett Island Bridge has no negative effect on abundance or richness.

All anuran species encountered in this study had been previously documented on the Ohio River Islands National Wildlife Refuge and are common along the Ohio River [60]. Habitat was the determining factor of anuran presence [61], and anuran abundance and richness in relation to the bridge indicated the bridge had no negative effect. Other research has indicated that anurans respond positively or neutrally to disturbance. Two endangered anuran species responded favorably or neutrally to ground disturbance on a military training area in Germany [62]. Populations of anurans in floodplain wetlands were similar in abundance and richness compared to less dynamic wetlands not in floodplains [63]. Also, anuran abundance and richness was stable at a suburban wildlife refuge despite large amounts of development in close proximity to wetlands [64].

\subsection{Turtles}

Turtles are tolerant of urbanization and anthropogenic changes in the landscape $[65,66]$. Our study indicated that turtle abundance and richness were no different among sites or at the different distances from the bridges indicating that the new bridge has no negative effect on these metrics. Additionally, the difference in diversity among sites had no attribution to the new bridge. Eastern spiny softshell and common snapping turtle represented the majority of captures which is comparable to other studies on the Ohio River [25]. Eastern spiny softshells were encountered only in the main river which coincides with habitat preferences for this species [67]. Common snapping turtles were found readily in the main river at each of the study islands but more frequently in back channels [25]. We believe the Ohio River supports a large population of these 2 species around the study areas due to quality and quantity of habitat in the form of sand and gravel bars, emergent vegetation, and woody debris.

The other 3 species (northern map turtle, Midland painted turtle, and stinkpot) were all encountered in low numbers. Each species is associated with slow bodies of water with soft bottoms and abundant basking sites [60] which are plentiful around Ohio River islands and in the slough on Blennerhassett, and we do not believe the bridge is affecting their abundances. Aquatic turtles are disturbance tolerant animals unlike many other taxa of wildlife. Spiny softshell turtle survival in Arkansas was not negatively affected when creek beds were bulldozed and woody debris was removed which decreased habitat quality and quantity [66]. Painted turtle nesting ecology showed no changes with increases of human recreation at a major nesting beach [68]. Species of freshwater turtles, including those found in this study, persist following disturbances in the form of urbanization [65] and in some cases may even be more abundant in urban habitats than they are in more undisturbed natural areas $[69,70]$.

\subsection{Small Mammals}

Small mammals are typically depicted as disturbance tolerant [71,72]. However, we found that combined small mammal abundance and abundances of Peromyscus spp. were lower under the new bridge indicating that it has impacts. Species richness and diversity also were lower under the new bridge compared to other distances indicating that the disturbance from construction of the bridge may result in a decrease in small mammal richness and diversity. We believe these impacts are due to the amount and type of vegetative cover, and preferences of microhabitat by certain species [73]. We suggest these impacts are temporary and that abundance, richness, and diversity under the bridge will increase to levels similar to other distances as shown at the older Buckley Island Bridge making it consistent with other studies following a disturbance $[74,75]$.

Total abundances of small mammals were highest at Blennerhassett, which is most likely due to more quality, quantity, and diversity of habitat. Lack of grasslands, old fields, and brushy areas at Muskingum Island [46] may be causing lower abundances [76], while possible reasons for lower abundance at Buckley Island include high numbers of raccoons preying on small mammals [77] or high intensity disturbance from agriculture, residential development, and urbanization. Also, all 3 sites may be experiencing variation due to cyclical fluctuations of small mammal populations [78,79].

The vegetation under the new bridge was of low coverage and consisted of herbaceous, disturbance tolerant plants typically used for reclamation making it similar to roadsides and may be the reason why abundances, richness, and diversity was low. However, capture rates and diversity increased under the bridge as vegetative cover 
increased during the study. We hypothesize that the low abundances, richness, and diversity under the bridge is temporary and will increase as vegetative coverage increases. Also, there was only one detection of a small mammal moving from transect to transect at all of the sites (one Peromyscus spp. moved from a $100 \mathrm{~m}$ transect to a $0 \mathrm{~m}$ transect at Blennerhassett) possibly indicating that small mammal populations were impacted under the bridge during construction and are slowly increasing as habitat is restored.

\subsection{Furbearers}

We found that combined furbearer detections did not differ among sites or distances. However, 2 species, raccoon and red fox, did vary. Raccoon detections were much lower at $0 \mathrm{~m}$ transects at Blennerhassett. These impacts could possibly be from habitat fragmentation and loss, most notably disturbance of natural shorelines caused by construction of the bridge. However, increased urbanization and habitat modification and fragmentation result in higher raccoon densities [79]. Raccoons respond well and use wildlife passages and underpasses [80] and we assume they use the area under the bridge similarly. We hypothesize that raccoons commonly frequent the area beneath the bridge, but may be patrolling around the wetland instead of the shorelines, thus avoiding our scent stations. Raccoon populations within the study area appear to be high due to high presence shown in scent station surveys, large amounts of tampering of small mammal traps during small mammal trapping periods, abundant quality and quantity of habitat (proximity to water, proximity to urban areas, and multiple cover types), lack of hunting and minimal trapping on the islands, and abundant food sources [77,81].

Red fox occurrences were highest at Blennerhassett and this species did not occur at Muskingum which is the reason for variation among sites and indicates the new bridge has no negative impacts. Personal observations suggest red fox populations are high on Blennerhassett as this island has preferred habitats including: forest, open areas, and grasslands and mixed vegetation communities such as edge habitats and mixed scrub and woodland [82].

\subsection{Conclusion}

Any disturbance is likely to have impacts on some species, either negatively or positively. Species adapted to man-made structures such as rock pigeons responded favorably to the bridge and some such as Carolina wrens responded negatively. However, most songbird and waterbird species displayed no effect. Indeed, variation among islands was greater than variation among distances for almost all taxa. The more aquatic taxa such as turtles and anurans showed no relative density effects from the bridge.
Overall, the new bridge had little significant impact on relative density of wildlife, but the bridge did impact community composition and relative abundance of some species. It is possible that more impacts would have been seen if the island did not have a long history of human impacts. Continued monitoring of this and other bridges is necessary to determine potential long-term impacts.

\section{Acknowledgements}

We thank the West Virginia Department of Transportation, Division of Highways for the funding of this project. We thank the US Fish and Wildlife Service, the West Virginia Division of Natural Resources Wildlife Resources Section and Recreation and Parks Section for their cooperation throughout this project. We thank Dr. Phil Turk, Dr. George Merovich and Dr. Jim Rentch for their assistance with statistical analysis for this project. Special thanks is also extended to the many biologists, field technicians, graduate students, and volunteers who assisted with this project including: Patty Morrison, Gary Batton, Jeff McCrady, Matt Baker, Craig Leibfreid, Graham Nesselrodt, Matt Coen, Brandon Miller, Tristan Gingerich, Walter Veselka, Gabe Strain, Kyle Aldinger, Mandy Weston, Curtis DeLong, Brian Reed, and David Vance. This is scientific article number 3143 of the West Virginia University Agriculture and Forestry Experiment Station.

\section{REFERENCES}

[1] B. L. Turner, II, W. C. Clark, R. W. Kates, J. F. Richards, J. T. Matthews and W. B. Meyer, "The Earth as Transformed by Human Actions: Global and Regional Changes in the Biosphere over the Past 300 Years," Cambridge University Press, Cambridge, 1991.

[2] M. L. McKinney, "Urbanization, Biodiversity, and Conservation," BioScience, Vol. 52, No. 10, 2002, pp. 883890.

[3] C. L. Arnold and C. Gibbons, "Impervious Surface Coverage. The Emergence of a Key Environmental Indicator," Journal of the American Planning Association, Vol. 62, No. 2, 1996, pp. 243-258.

[4] N. B. Grimm, J. M. Grove, S. T. A. Pickett and C. L. Redman, "Integrated Approaches to Long-Term Studies of Urban Ecological Systems," BioScience, Vol. 50, No. 7, 2000, pp. 571-584.

[5] L. W. Adams, "Urban Wildlife Habitats: A Landscape Perspective," University of Minnesota Press, Minneapolis, 1994.

[6] B. Czech and P. R. Krausman, "Distribution and Causation of Species Endangerment in the United States," Science, Vol. 277, No. 5329, 1997, pp. 1116-1117.

[7] R. T. Forman, D. Sperling, J. A. Bissonette, A. P. Clevenger, C. D. Cutshall, V. H. Dale, L. Fahrig, R. France, C. R. Goldman, K. Heanue, J. A. Jones, F. J. Swanson, T. Turrentine and T. C. Winter, "Road Ecology: Science and 
Solutions," Island Press, Washington DC, 2003.

[8] D. Macpherson, J. L. Macpherson and P. Morris, "Rural Roads as Barriers to the Movements of Small Mammals," Applied Ecology and Environmental Research, Vol. 9, No. 2, 2011, pp. 167-180.

[9] L. J. Redmond and M. T. Murphy, "Unusual Barn Swallow Nest Placement in Southeastern Oregon," Wilson Journal of Ornithology, Vol. 119, No. 2, 2007, pp. 307-309.

[10] R. Tumlison, "Breeding by Cliff Swallows (Petrochelidon pyrrhonota) in Southern Arkansas," Southwestern Naturalist, Vol. 54, No. 2, 2009, pp. 208-210.

[11] D. A. Bell, D. P. Gregoire and B. J. Walton, "Bridge Use by Peregrine Falcons in the San Francisco Bay Area," In: D. M. Bird, D. Varland and J. Negro, Eds., Raptors in Human Landscapes: Adaptations to Built and Cultivated Environments, Academic Publishers, San Diego, 1996, pp. 15-24.

[12] F. B. Bennett, S. C. Loeb, M. S. Bunch and W. W. Bowerman, "Use and Selection of Bridges as Day Roosts by Rafinesque's Big-Eared Bats," American Midland Naturalist, Vol. 160, No. 2, 2008, pp. 386-399.

[13] W. D. Clark and J. R. Karr, "Effect of Highways on RedWinged Blackbird and Horned Lark Populations," Wilson Bulletin, Vol. 91, No. 1, 1979, pp. 143-145.

[14] T. Haxton, "Road Mortality of Snapping Turtles, Chelydra serpentina, in Central Ontario during Their Nesting Period," Canadian Field Naturalist, Vol. 114, No. 1, 2000, pp. 106-110.

[15] M. W. Hubbard, B. J. Danielson and R. A. Schmitz, "Factors Influencing the Location of Deer-Vehicle Accidents in Iowa," Journal of Wildlife Management, Vol. 64, No. 3, 2000, pp. 707-712.

[16] J. B. Breeden, F. Hernandez, R. L. Bingham, N. J. Silvy and G. L. Waggerman, "Effects of Traffic Noise on Auditory Surveys of Urban White-Winged Doves," Wilson Journal of Ornithology, Vol. 120, No. 2, 2008, pp. 384-389.

[17] R. F. Noss, H. B. Quigley, M. G. Hornocker, T. Merrill and P. C. Paquet, "Conservation Biology and Carnivore Conservation in the Rocky Mountains," Conservation Biology, Vol. 10, No. 4, 1996, pp. 949-963.

[18] J. L. Vankat and D. G. Roy, "Landscape Invisibility by Exotic Species," In: K. J. Gutzwiller, Ed., Applying Landscape Ecology in Biological Conservation, Springer, New York, 2002, pp. 170-192. doi:10.1007/978-1-4613-0059-5 10

[19] S. C. Trombulak and C. A. Frissell, "Review of Ecological Effects of Roads on Terrestrial and Aquatic Communities," Conservation Biology, Vol. 14, No. 1, 2000, pp. 1830.

[20] R. T. Forman, "Estimate of the Area Affected Ecologically by the Road System in the United States," Conservation Biology, Vol. 14, No. 1, 2000, pp. 31-35.

[21] M. M. Rowland, M. J. Wisdom, B. K. Johnson and J. G. Kie, "Elk Distribution and Modeling in Relation to Roads," Journal of Wildlife Management, Vol. 64, No. 3, 2000, pp. 672-684.

[22] GoBridges, "Rebuilding America's Infrastructure," 2009. http://www.rebuildingamericasinfrastructure.com/tag-brid ges-1.html?id=323

[23] W. A. Tolin and P. A. Schettig, "A Physical and Biological Survey of the Ohio River Islands (Huntington District)," US Fish and Wildlife Service, Elkins, 1983.

[24] Idcide West Virginia Weather, "West Virginia Profile," 2010. http://www.idcide.com/weather/wv/

[25] A. K. Zadnik, J. T. Anderson, P. B. Wood and K. Bledsoe, "Wildlife Use of Back Channels Associated with Islands on the Ohio River," Wetlands, Vol. 29, No. 2, 2009, pp. 543-551.

[26] A. E. Burger, "Using Radar to Estimate Populations and Assess Habitat Associations of Marbled Murrelets," Journal of Wildlife Management, Vol. 65, No. 4, 2001, pp. 696715 .

[27] H. W. Heusmann and J. R. Sauer, "The Northeastern States' Waterfowl Breeding Population Survey," Wildlife Society Bulletin, Vol. 28, No. 2, 2000, pp. 355-364.

[28] L. W. Lougheed and A. Breault, "Estimating Statistical Power to Evaluate Ongoing Waterfowl Population Monitoring," Journal of Wildlife Management, Vol. 63, No. 1, 1999, pp. 359-1369.

[29] M. W. Weller, "Wetland Birds, Habitat Resources and Conservation," Cambridge University Press, New York, 1999. doi:10.1017/CBO9780511541919

[30] L. B. Best, I. H. Campa, K. E. Kemp, R. J. Robel, M. R. Ryan, J. A. Savidge, J. H. P. Weeks and S. R. Winterstein, "Bird Abundance and Nesting in CRP Fields and Cropland in the Midwest: A Regional Approach," Wildlife Society Bulletin, Vol. 25, No. 4, 1997, pp. 864-877.

[31] G. M. Forcey, J. T. Anderson, F. K. Ammer and R. C. Whitmore, "Comparison of Two Double-Observer PointCount Approaches for Estimating Breeding Bird Abundance," Journal of Wildlife Management, Vol. 70, No. 6, 2006, pp. 1674-1681.

[32] C. K. Balcombe, J. T. Anderson, R. H. Fortney and W. S. Kordek, "Wildlife Use of Mitigation and Reference Wetlands in West Virginia," Ecological Engineering, Vol. 25, No. 1, 2005, pp. 85-99.

[33] M. Mossman, "Wisconsin Frogs and Toads Survey Instructions," Endangered Species Branch, Department of Natural Resources, Madison, 1994.

[34] F. R. Cagle, "A System of Marking Turtles for Future Identification," Copeia, Vol. 1939, No. 3, 1939, pp. 170173.

[35] W. J. Breckenridge, "Observations on the Life History of the Soft-Shelled Turtle Trionyx," Copeia, Vol. 1955, No. 1, 1955, pp. 5-9. doi:10.2307/1439445

[36] D. F. Pearson and L. F. Ruggiero, "Transects versus Grid Trapping Arrangements for Sampling Mammal Communities," Wildlife Society Bulletin, Vol. 31, No. 2003, pp. 454459.

[37] J. A. Edalgo and J. T. Anderson, "Effects of Prebaiting on Small Mammal Trapping Success in a Morrow's Honeysuckle-Dominated Area," Journal of Wildlife Management, Vol. 71, No. 1, 2007, pp. 246-250.

[38] M. A. Menzel, W. M. Ford, J. Laerm and D. Krishon, 
"Forest to Wildlife Openings: Habitat Gradient Analysis among Small Mammals in the Southern Appalachians," Forest Ecology and Management, Vol. 114, No. 2-3, 1999, pp. 227-232.

[39] D. A. Helon, J. T. Anderson and J. D. Osbourne, "Comparison of Interior versus Roadside Scent Stations," Game and Wildlife Science, Vol. 19, No. 4, 2002, pp. 303-312.

[40] W. J. Conover and R. L. Iman, "Rank Transformations as a Bridge between Parametric and Non-Parametric Statistics," American Statistician, Vol. 35, No. 3, 1981, pp. 124129.

[41] W. J. Conover, "Practical Nonparametric Statistics," John Wiley and Sons, New York, 1999.

[42] M. J. Anderson, "A New Method for Non-Parametric Multivariate Analysis of Variance," Austral Ecology, Vol. 26, No. 1, 2001, pp. 32-46.

[43] B. McCune and M. J. Mefford, "PCORD for Windows: Multivariate Analysis of Ecological Data," Version 4.0, MjM Software, Glenedon Beach, 1999.

[44] B. McCune, J. B. Grace and D. L. Urban, "Analysis of Ecological Communities," MjM Software Design, Glenedon Beach, 2002.

[45] M. Dufrene and P. Legendre, "Species Assemblages and Indicator Species: The Need for a Flexible Asymmetrical Approach," Ecological Monographs, Vol. 67, No. 3, 1997, pp. 345-366.

[46] J. A. Vance, "Evaluating the Effects of the Blennerhassett Island Bridge Crossing (Ohio River) on Soil, Vegetation, and Wildlife," M.S. Thesis, West Virginia University, Morgantown, 2010.

[47] J. P. Gibbs, S. Woodward, M. L. Hunter and A. E. Hutchinson, "Determinants of Great Blue Heron Colony Distribution in Coastal Maine," Auk, Vol. 104, No. 1, 1987, pp. 38-47.

[48] B. D. Watts and D. S. Bradshaw, "The Influence of Human Disturbance on the Location of Great Blue Heron Colonies in the Lower Chesapeake Bay," Colonial Waterbirds, Vol. 17, No. 2, 1994, pp. 184-186.

[49] M. M. Grubb, "Effects of Increased Noise on Nesting Herons and Egrets," Proceedings of the Colonial Waterbird Group, Vol. 2, No. 1979, pp. 49-54.

[50] R. G. Vennesland and R. W. Butler, "Factors Influencing Great Blue Heron Nesting Productivity on the Pacific Coast of Canada from 1998 to 1999," Waterbirds, Vol. 27, No. 3, 2004, pp. 289-296.

[51] J. M. Burris and A. W. Haney, "Bird Communities after Blowdown in Late Successional Great Lakes Spruce-Fir Forest," Wilson Bulletin, Vol. 117, No. 4, 2005, pp. 341352.

[52] P. B. Pearman, "The Scale of Community Structure: Habitat Variation and Avian Guilds in Tropical Forest Understory," Ecological Monographs, Vol. 72, No. 1, 2002, pp. 19-39.

[53] T. B. Wigley and R. A. Lancia, "Wildlife Communities," In: M. G. Messina and W. H. Conner, Eds., Southern Forested Wetlands, Lewis Publishers, New York, 1998, pp. 205-236

[54] J. L. Morissette, T. P. Cobb, R. M. Brigham and P. C.
James, "The Response of Boreal Forest Songbird Communities to Fire and Post-Fire Harvesting," Canadian Journal of Forest Research, Vol. 32, No. 12, 2002, pp. 2169 2183.

[55] K. A. Hobson and J. Schieck, "Changes in Bird Communities in Boreal Mixedwood Forest: Harvest and Wildfire Effects over 30 Years," Ecological Applications, Vol. 9, No. 3, 1999, pp. 849-863. doi:10.1890/1051-0761(1999)009[0849:CIBCIB]2.0.CO; $\underline{2}$

[56] B. Zuckerberg and P. D. Vickery, "Effects of Mowing and Burning on Shrubland and Grassland Birds on Nantucket Island, Massachusetts," Wilson Journal of Ornithology, Vol. 118, No. 3, 2006, pp. 353-363.

[57] E. A., Odell and R. L. Knight, "Songbird and MediumSized Mammal Communities Associated with Exurban Development in Pitkin, County, Colorado," Conservation Biology, Vol. 15, No. 4, 2001, pp. 1143-1150.

[58] S. J. Price, R. W. Howe, J. M. Hanowski, R. R. Regal, G. J. Niemi and C. R. Smith, "Are Anurans of Great Lake Coastal Wetlands Reliable Indicators of Ecological Condition," Journal of Great Lakes Research, Vol. 33, No. 3, 2007, pp. 211-223.

[59] L. J. Vitt, J. P. Caldwell, H. M. Wilbur and D. C. Smith, "Amphibians as Harbingers of Decay," BioScience, Vol. 40, No. 6, 1990, p. 418.

[60] N. B. Green and T. K. Pauley, "Amphibians and Reptiles in West Virginia," University of Pittsburgh Press, Pittsburgh, 1987.

[61] G. H. Dayton, R. E. Jung and S. Droege, "Large Scale Habitat Association of Four Desert Anurans in Big Bend National Park, Texas," Journal of Herpetology, Vol. 38, No. 4, 2004, pp. 619-627.

[62] S. D. Warren and R. Buttner, "Relationship of Endangered Amphibians to Landscape Disturbance," Journal of Wildlife Management, Vol. 72, No. 3, 2008, pp. 738-744.

[63] J. A. Henning and G. Schirato, "Amphibian Use of Chehalis River Floodplain Wetlands," Northwestern Naturalist, Vol. 87, No. 3, 2006, pp. 209-214.

[64] S. M. Brander, J. A. Royle and M. Eames, "Evaluation of the Status of Anurans on a Refuge in Suburban Maryland," Journal of Herpetology, Vol. 41, No. 1, 2007, pp. 52-60.

[65] C. A. Conner, B. A. Douthitt and T. J. Ryan, "Descriptive Ecology of a Turtle Assemblage in an Urban Landscape," American Midland Naturalist, Vol. 153, No. 2, 2005, pp. 428-435.

[66] M. V. Plummer, D. G. Krementz, L. A. Powell and N. E. Mills, "Effects of Habitat Disturbance on Survival Rates of Softshell Turtles (Apalone spinifera) in an Urban Stream," Journal of Herpetology, Vol. 42, No. 3, 2008, pp. 555563.

[67] D. D. Wright, M. A. Bozek, J. R. Probst and E. M. Anderson, "Response of Turtle Assemblage to Environmental Gradients in the St., Croix River in Minnesota and Wisconsin, USA," Canadian Journal of Zoology, Vol. 77, No. 6, 1999, pp. 989-1000.

[68] K. D. Bowen and F. J. Janzen, "Human Recreation and the Nesting Ecology of a Freshwater Turtle (Chrysemys 
picta)," Chelonian Conservation and Biology, Vol. 7, No. 1, 2008, pp. 95-100.

[69] A. Gasith and I. Sidis, "Polluted Water Bodies, the Main Habitat of the Caspian Terrapin (Mauremys caspica rivulata) in Israel," Copeia, Vol. 1984, No. 11, 984, pp. 216219.

[70] P. V. Lindeman, "Comparative Life History of Painted Turtle (Chrysemys picta) in Two Habitats in the Inland Pacific Northwest," Copeia, Vol. 1996, No. 1, 1996, pp. 114-130.

[71] A. G. Elliott and B. G. Root, "Small Mammal Responses to Silvicultural and Precipitation-Related Disturbance in Northeastern Missouri Riparian Forests," Wildlife Society Bulletin, Vol. 34, No. 2, 2006, pp. 485-501.

[72] G. L. Kirkland, "Patterns of Initial Small Mammal Community Change after Clearcutting of Temperate North American Forests," Oikos, Vol. 59, No. 3, 1990, pp. 313320.

[73] M. Silva and M. E. Prince, "The Conservation Value of Hedgerows for Small Mammals in Prince Edward Island, Canada," American Midland Naturalist, Vol. 159, No. 1, 2008, pp. 110-124.

[74] L. Hansson, "Small Mammal Communities on Clearcuts in a Latitudinal Gradient," Acta Ecology, Vol. 13, No. 6, 1992, pp. 687-699.

[75] T. P. Sullivan, R. A. Lautenschlager and R. G. Wagner, "Clearcutting and Burning of Northern Spruce-Fir Forests: Implications for Small Mammal Communities," Journal of Applied Ecology, Vol. 36, No. 3, 1999, pp. 327-344.

[76] V. A. Barko, G. A. Feldhamer, M. C. Nicholson and D. K. Davie, "Urban Habitat: A Determinant of White-Footed Mouse (Peromyscus leucopus) Abundances in Southern Illinois," Southeastern Naturalist, Vol. 2, No. 3, 2003, pp. 369-376.

[77] F. Okabe and N. Agetsuma, "Habitat Use by Introduced Raccoons and Native Raccoon Dogs in a Deciduous Forest in Japan," Journal of Mammalogy, Vol. 88, No. 4, 2007, pp. 1090-1097.

[78] S. P. Elias, J. W. Witham and M. L. Hunter Jr., "Peromyscus leucopus Abundance and Acorn Mast: Population Fluctuations over 20 Years," Journal of Mammalogy, Vol. 85, No. 4, 2004, pp. 743-747.

[79] C. O. Hoffman and J. L. Gottschang, "Numbers, Distribution, and Movements of a Raccoon Population in a Suburban Residential Community," Journal of Mammalogy, Vol. 58, No. 4, 1977, pp. 623-636.

[80] M. L. Foster and S. R. Humphrey, "Use of Highway Underpasses by Florida Panthers and Other Wildlife," Wildlife Society Bulletin, Vol. 23, No. 1, 1995, pp. 95-100.

[81] J. C. Beasley, T. L. Devault, M. I. Retamosa and O. E. Rhodes Jr., "A Hierarchical Analysis of Habitat Selection by Raccoons in Northern Illinois," Journal of Wildlife Management, Vol. 71, No. 4, 2007, pp. 1125-1133.

[82] J. M. Weber and J. S. Meia, "Habitat Use by the Red Fox Vulpes vulpes in a Mountainous Region," Ethology Ecology and Evolution, Vol. 8, No. 3, 1996, pp. 223-232. 


\section{Appendix 1. Common and Scientific Names of Species in Tables}

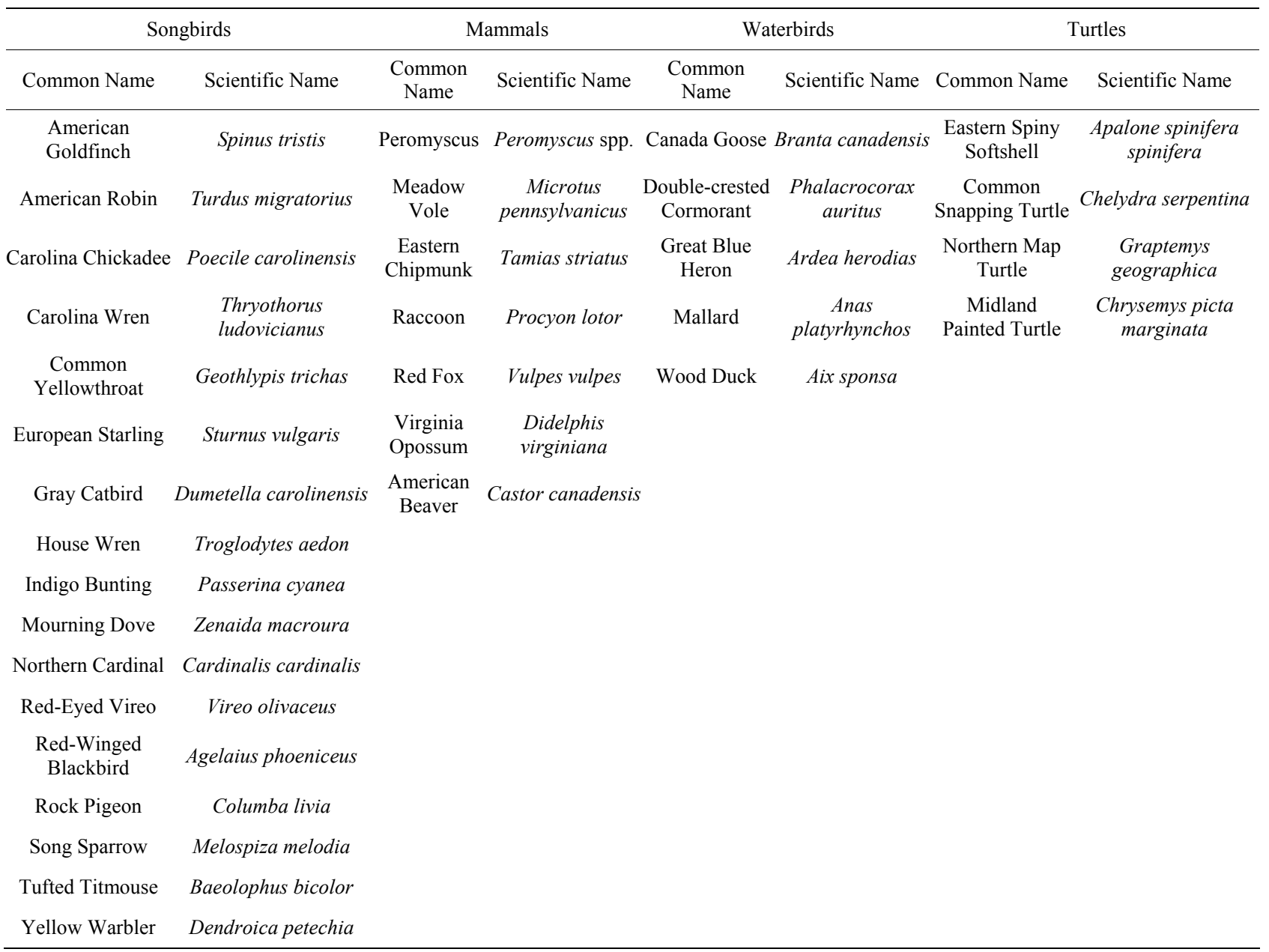

